\title{
Obstructive sleep apnea and comorbidities: a dangerous liaison
}

\author{
Maria R. Bonsignore ${ }^{1,2^{*}}$ D, Pierpaolo Baiamonte ${ }^{1}$, Emilia Mazzuca', Alessandra Castrogiovanni ${ }^{3}$ and Oreste Marrone $^{2}$
}

\begin{abstract}
Obstructive sleep apnea (OSA) is a highly prevalent disease, and is traditionally associated with increased cardiovascular risk. The role of comorbidities in OSA patients has emerged recently, and new conditions significantly associated with OSA are increasingly reported. A high comorbidity burden worsens prognosis, but some data suggest that CPAP might be protective especially in patients with comorbidities. Aim of this narrative review is to provide an update on recent studies, with special attention to cardiovascular and cerebrovascular comorbidities, the metabolic syndrome and type 2 diabetes, asthma, COPD and cancer. Better phenotypic characterization of OSA patients, including comorbidities, will help to provide better individualized care. The unsatisfactory adherence to CPAP in patients without daytime sleepiness should prompt clinicians to examine the overall risk profile of each patient in order to identify subjects at high risk for worse prognosis and provide the optimal treatment not only for OSA, but also for comorbidities.
\end{abstract}

Keywords: Mortality, prognosis, cardiovascular disease, diabetes, asthma, COPD, cancer

Obstructive sleep apnea (OSA) is highly prevalent in the general population, and occurs at all ages [1]. OSA is characterized by collapse of upper airways during sleep with ineffective respiratory efforts, intermittent hypoxia and sleep disruption. Continuous positive airway pressure (CPAP), mandibular advancement devices, and upper airway (UA) and maxillo-facial surgery are therapeutic options that prevent UA closure during sleep, CPAP being the gold standard for moderate-severe OSA. The typical OSA patient is overweight or obese, sleepy in passive situations or while driving, and often affected by systemic hypertension, type 2 diabetes, and dyslipidemia [1].

The frequent association of OSA with metabolic and cardiovascular diseases has been recognized since the early studies, but the role of OSA as an independent risk factor has long remained controversial due to the presence of powerful confounders, such as hypertension and obesity [2]. Interest in the role of comorbidities in OSA has grown in the last decade, as shown by the rising number of publications on the topic (Fig. 1). This review will

\footnotetext{
* Correspondence: marisa@ibim.cnr.it

${ }^{1}$ Division of Respiratory Medicine, Biomedical Department of Internal Medicine and Medical Specialties (Di.Bi.M.I.S), University Hospital Paolo Giaccone, University of Palermo, Piazza delle Cliniche, 2, 90100 Palermo, Italy ${ }^{2}$ National Research Council (CNR), Institute of Biomedicine and Molecular Immunology (IBIM), Palermo, Italy

Full list of author information is available at the end of the article
}

examine some epidemiological aspects of comorbidities in OSA, and summarizes the current state of the art on the most frequent comorbidities encountered in clinical practice in OSA patients.

\section{Comorbidities in OSA: the size of the problem}

Currently, comorbidities are a major topic in clinical research on OSA. Several recent studies reported a high prevalence of comorbidities in OSA patients [3-6] (Fig. 2 ). The distribution of comorbidities differed between men and women, with diabetes and ischemic heart disease being more prevalent in men with OSA, and hypertension and depression being more prevalent in women with OSA compared to non-OSA subjects [3, 7]. According to some studies, the comorbidity burden progressively increases with OSA severity $[5,6,8,9]$.

A recent study from Taiwan in a large number of OSA patients analyzed prevalence of comorbidities at diagnosis and their relationship with mortality risk during follow up [10]. The study confirmed that OSA patients show a high prevalence of cardiovascular diseases (systemic hypertension, coronary artery disease, arrhythmias, ischemic stroke), respiratory diseases (COPD, asthma), and metabolic disorders (diabetes mellitus, dyslipidemia, gout). Many other disorders were also identified, including peptic ulcer disease, gastroesophageal reflux, chronic liver 


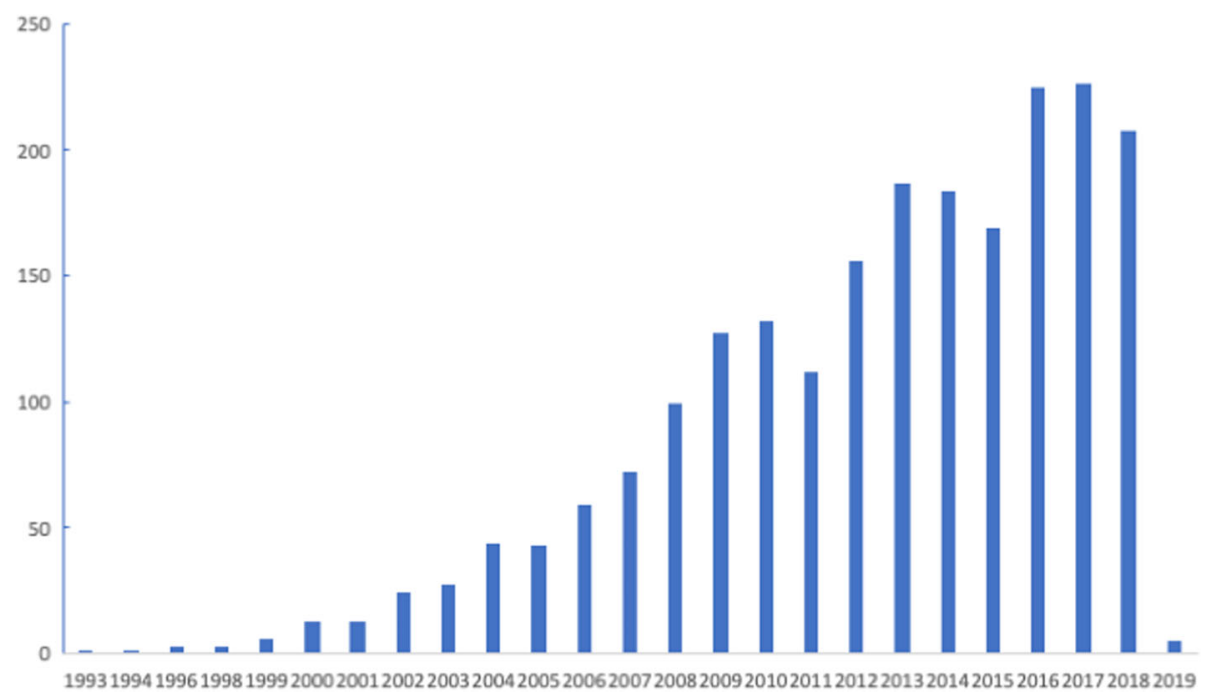

Fig. 1 Retrieval of references by searching PubMed for "obstructive sleep apnea" and comorbidities, 9 Jan 2019

disease, anxiety, insomnia, and depression. The authors identified ten comorbid conditions associated with increased mortality risk, and developed a comorbidity score for OSA by taking into account the relative risk associated with each disease state and the number of comorbidities. Such an approach allows to focus on those comorbidities that are prognostically more relevant in OSA. For example, the highest risk was associated with end-stage renal disease and aortic aneurysm, which showed the lowest prevalence in the sample [10]. In addition, the higher the comorbidity score, the higher the mortality risk [10]. Unfortunately, the impact of OSA treatment was not evaluated in detail.
Comorbidities and mortality in CPAP-treated OSA

Other studies on the prognostic impact of comorbidities in OSA patients examined the effects of CPAP treatment. In a large study from Denmark, negative predictors for survival were male gender, age $\geq 60$ years, no CPAP treatment, prior comorbidity, and low educational level [11]. Another study found that age and occurrence of comorbidities predicted mortality in OSA patients [12]. In patients aged $>50$ years, protective effects of CPAP treatment were shown only in patients with comorbidities [12]. In patients with moderatesevere obesity and OSA, treatment with CPAP or noninvasive ventilation was associated with fewer cardiovascular events only in patients with a high number of comorbidities

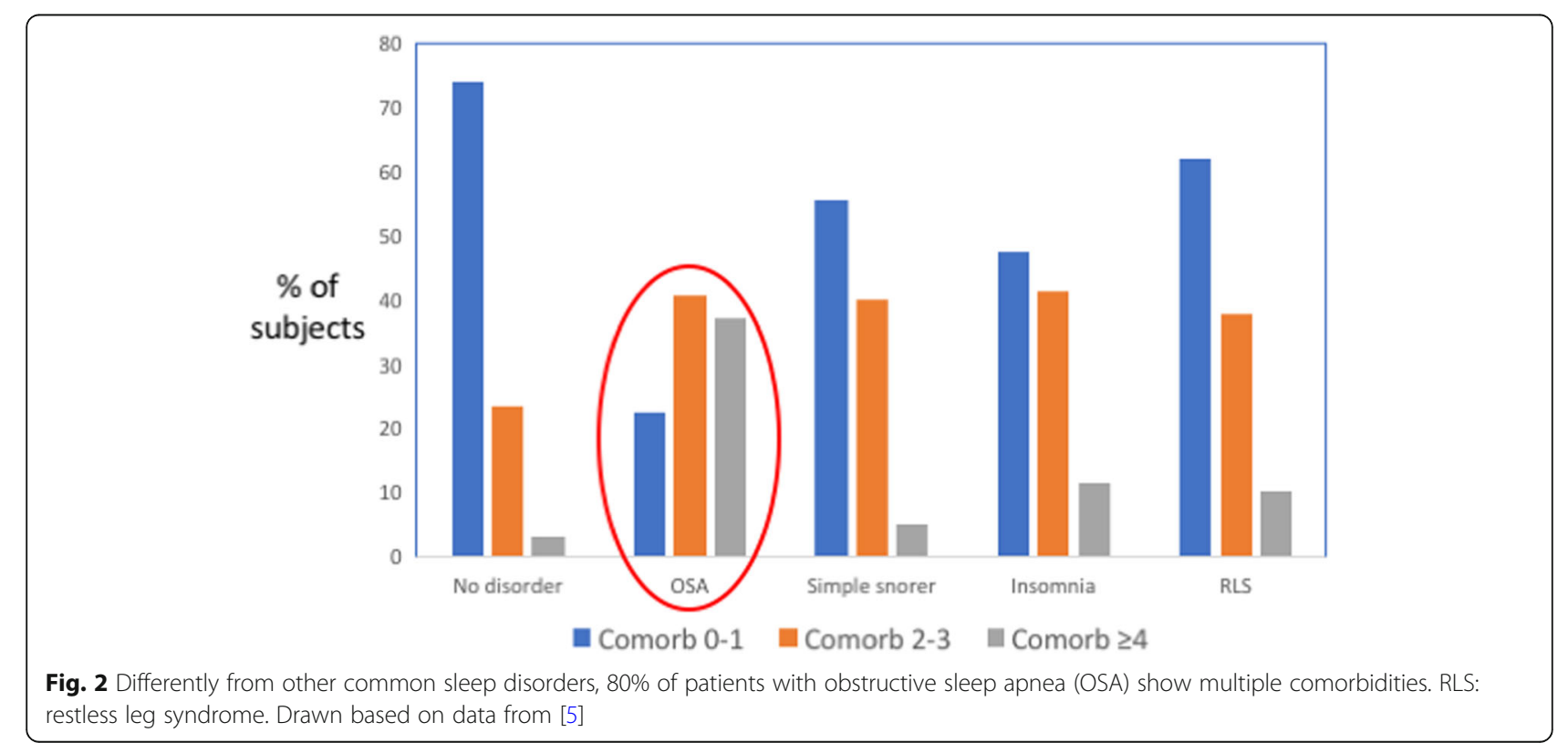


[13]. The protective effect of CPAP might be larger in males than females with OSA $[14,15]$. Other observational studies reported a protective effect of CPAP treatment in elderly OSA patients, who usually show a high prevalence of cardiometabolic comorbidities [16, 17].

Therefore, occurrence of comorbidities could identify subgroups of OSA patients at high risk, who might show benefit from CPAP treatment. Several studies have tried to define clinical phenotypes of OSA, and a cluster of patients with few OSA symptoms but high comorbidity burden has been reported by most studies published so far; such a cluster at least partly overlaps with the cluster of elderly OSA patients [18]. More recent analyses pointed to sleep fragmentation and hypoxia as risk factors for cardiovascular events or death, and regular CPAP use appeared to exert a protective effect [19].

\section{Common comorbidities in OSA patients}

A comprehensive review of all possible comorbidities associated with OSA is beyond the scope of this article. Only the most frequent diseases will be discussed, with special attention to the most recent publications.

\section{Cardiovascular and cerebrovascular diseases}

Many studies have examined the role of OSA as a pathogenetic factor in cardiovascular and cerebrovascular diseases, as well as the potential protective effects of CPAP treatment. OSA may increase cardiovascular risk through multiple intermediate mechanisms, such as intermittent hypoxia, high sympathetic nervous activity, systemic hypertension, endothelial cell dysfunction, oxidative stress, inflammation, and accelerated atherosclerosis [1]. On the other hand, chronic intermittent hypoxia could also activate some protective mechanisms, for example through the development of coronary vessel collaterals in patients with ischemic heart disease [20, 21].

\section{Systemic hypertension}

The best studied cardiovascular comorbidity in OSA is systemic hypertension [22]. Respiratory events during sleep are associated with hypertensive peaks occurring at the end of apneas and hypopneas, increased mean nocturnal blood pressure, and increased variability of blood pressure [23]. A dose-response relationship has been shown between OSA severity and blood pressure [24]. OSA patients may show elevated blood pressure values during sleep only, or during sleep and wakefulness, making 24-hour monitoring of blood pressure highly advisable in the OSA population [22]. Resistant hypertension, i.e. incomplete blood pressure control on three antihypertensive drugs, is also frequent in OSA patients.

Several studies assessed the potential benefit of CPAP treatment on blood pressure values, and meta-analyses demonstrated that on average blood pressure decreased by only a small amount during CPAP treatment. However, the therapeutic effect of CPAP on hypertension varied according to OSA severity, compliance to CPAP treatment, and baseline blood pressure values [25]. OSA patients with resistant hypertension showed a quite large decrease in blood pressure during CPAP [26]. Antihypertensive drugs, and diuretics in particular, may slightly decrease AHI in OSA [27]. In general, pharmacological treatment to control hypertension is necessary in hypertensive OSA patients, given the small effects of CPAP on blood pressure $[28,29]$.

\section{Cardiovascular events and/or death}

Several studies have addressed the question of OSA and cardiovascular morbidity and mortality. The prospective cohort study by Marin and coworkers reported a high cardiovascular risk in patients with severe OSA, which was normalized by CPAP treatment [30]. The results of observational studies confirmed the association of untreated OSA with overall and cardiovascular mortality [31]. In patients undergoing percutaneous coronary intervention, OSA was associated with occurrence of cardiovascular events during follow up [32, 33].

Randomized controlled trials (RCTs) in OSA patients with known coronary artery or cerebrovascular disease were then designed to verify whether treatment of OSA in patients at high cardiovascular risk might exert a protective role. However, RCTs on the effects of CPAP in patients with known coronary or cerebrovascular disease failed to show any protective effect of CPAP treatment on cardiovascular risk [34]. Current uncertainty is due to the discrepancy between data obtained from observational studies and RCTs [35]. Different patients' characteristics according to the type of study may explain the different results. In particular, only patients without excessive daytime sleepiness were included in long-term RCTs, since it would be unethical to withdraw treatment in symptomatic patients. It is known that compliance to CPAP treatment in non-sleepy patients is low, as underlined in a recent pro-con debate [36, 37]. Good compliance to CPAP, i.e. mean nightly use $\geq 4$ hours, was associated with some protection, especially for occurrence of stroke [38].

Another area of current interest is whether OSA may modify the outcomes of acute coronary syndromes (ACS). OSA prevalence is high in patients with ACS, and severe OSA occurs in $25 \%$ of the patients [39]. The ongoing ISAACC trial (Impact of Continuous Positive Airway Pressure on Patients with ACS and Nonsleepy OSA) will provide long-term data on the effects of treating OSA in this population [40]. 


\section{Arrhythmias}

Arrhythmias are frequent in OSA patients, especially atrial fibrillation (AF). A permissive role of OSA towards the arrhythmogenic mechanism of AF is suggested by the higher risk of recurrence of AF in patients with OSA compared to non-OSA subjects and by the protective effect of CPAP treatment [41, 42]. Conversely, the literature on ventricular arrhythmias is relatively scarce and heterogeneous, as pointed out by a recent review [43]. Incidence of sudden cardiac death is increased at night in OSA according to some reports [44] while other studies found a uniform distribution over 24 hours [45]. Studies in patients with implantable cardioverter-defibrillator devices (ICD) have reported a high frequency of nocturnal discharge in OSA compared to non-OSA patients [46] or patients with chronic heart failure and central apneas $[47,48]$.

\section{Cerebrovascular disease}

Several studies reported an increased risk of stroke in snorers [49] and OSA patients [50]. CPAP treatment may reduce the risk of stroke [51], but most studies have used a composite cardiovascular outcome including stroke, rather than reporting data for each type of events. Available RCTs on the effects of CPAP in patients with stroke and OSA are usually short-term, and the low acceptance of CPAP treatment in patients with OSA and previous stroke is an additional difficulty to be considered. A recent meta-analysis on RCTs in the latter population reported improvement in neurological function in CPAP users [52]. More studies are necessary to evaluate the possible protective effects of CPAP on survival after stroke.

\section{Metabolic diseases}

The relationship between OSA and metabolism is highly complex. On one hand, OSA is often associated with obesity, which by itself is characterized by disturbed energy metabolism and adipose tissue inflammation [53]. On the other hand, nocturnal intermittent hypoxia has been shown to affect glucose metabolism, and OSA could independently contribute to the pathogenesis of metabolic disorders [54]. The bidirectional relationships between OSA and disturbed energy metabolism [55] or type 2 diabetes [56] are current topics of interest, given the obesity epidemics and the increasing prevalence of type 2 diabetes worldwide.

\section{OSA and the Metabolic Syndrome}

The metabolic syndrome (MetS), a pre-diabetic state associated with central obesity and increased cardiovascular risk [57], is highly prevalent in OSA patients [58] and, according to some authors, OSA should be considered as an additional manifestation of MetS [59]. OSA may play a role in the pathogenesis of insulin resistance, the main feature of MetS, through intermittent hypoxia $[60,61]$ and sleep loss or fragmentation [62-64]. A fascinating recent research area is represented by the role of gut microbiota in metabolic derangements induced by intermittent hypoxia [65, 66] or sleep fragmentation [67]. Readers interested in the complex mechanisms of the interaction between OSA/intermittent hypoxia, adipocyte dysfunction, and inflammatory activation in adipose tissue, are referred to extensive reviews on these topics [68-71].

Although a positive effect of OSA treatment on metabolic disturbances might be expected based on the pathophysiological links described above, CPAP treatment does not modify visceral fat or metabolic variables [72, 73] unless concurrent weight loss occurs [74]. Nevertheless, short-term CPAP treatment for 8 hours/night improves insulin resistance, suggesting that prolonged nightly treatment with CPAP may be needed to modify glucose metabolism in OSA, possibly through decreased sympathetic activation [75]. Activity of insulin in the carotid body, and a common pathway involving both intermittent hypoxia and metabolism, is an interesting recent pathogenetic hypothesis possibly explaining the intertwining effects of OSA and glucose dysmetabolism [76].

\section{OSA and diabetes}

The bidirectional relationship between OSA and diabetes is especially interesting from a clinical point of view [77]. Treatment of OSA may help to prevent severe consequences of diabetes. This might indeed be the case, since although glycemic control does not improve during CPAP treatment according to meta-analyses [78, 79], untreated OSA in diabetic patients is associated with increased prevalence of neuropathy [80], peripheral arterial disease [81], diabetic retinopathy [82] and diabetic nephropathy [83-85]. Data on the effects of CPAP on diabetic complications are scarce. Compared to poorly compliant patients, optic nerve function improved in severe OSA patients with good compliance to CPAP treatment [86]. A recent post-hoc analysis of data from the SAVE study highlighted a higher risk of adverse outcomes in diabetic compared to non-diabetic patients, and a protective effect of CPAP on recurrent cardiovascular events only in diabetic patients with OSA showing a good adherence to CPAP treatment, i.e. at least $4 \mathrm{~h} /$ night, in the first 2 years of the study [87].

In summary, OSA may worsen metabolic abnormalities, and OSA treatment with sufficient adherence could play a protective role, especially when concomitant lifestyle interventions and weight loss are implemented. Screening for OSA in diabetic patients should be systematically done, since CPAP treatment for at least $4 \mathrm{~h} /$ night may be protective, especially when diabetic complications are also present [88]. 


\section{Renal disease}

Renal diseases and OSA share common risk factors, like arterial hypertension, diabetes mellitus, obesity and advanced age. Each of such factors may give some independent contribution to the onset and progression of the other one [89]. OSA may endanger the kidney through several interacting mechanisms, including nocturnal intermittent hypoxemia, recurrent nocturnal blood pressure peaks, sympathetic hyperactivity, hyperactivation of intrarenal renin-angiotensin system, oxidative stress and systemic inflammation, endothelial dysfunction. A relationship between nocturnal hypoxemia and hyperactivation of the intrarenal renin-angiotensin system has been experimentally demonstrated [90].

Cross-sectional epidemiological studies have not consistently reported an association between OSA and either albumin excretion or eGFR. When an association was found, either severity of nocturnal hypoxemia [91] or the apnea/hypopnea index [92] were reported to correlate to renal alterations. These studies highly differed in design, sample size, recruitment criteria (patients referred to sleep laboratories, general population, diabetes as an inclusion or an exclusion criterion), so that it is difficult to draw firm conclusions from them.

More interesting and consistent results were obtained from longitudinal investigations. In a large study on US veterans, the annual rate of decline of eGFR was higher among patients diagnosed with sleep apnea than among controls [93]. Three retrospective cohort studies in Taiwan found a higher incidence of chronic kidney disease (any stage) among OSA than control subjects [94-96]. However, all these studies lacked polysomnographic information about OSA severity. Another longitudinal study on patients recruited in a sleep laboratory found that an accelerated decline in eGFR was more common among subjects who spent $>12 \%$ of sleep time with oxygen saturation $<90 \%$ than in less hypoxic subjects [97]. By contrast, a long-term study on the population-based Wisconsin Sleep Cohort did not find any difference in the rate of decline of eGFR between subjects initially showing an AHI $>15$ and other subjects [98]. However, the less severe nocturnal hypoxemia in sleep apnea subjects from the general population may at least partly explain the different results obtained in the Wisconsin cohort and in studies on OSA patients.

Most papers on the effects of OSA treatment on kidney function showed positive effects of CPAP. Two small studies on subjects with a high baseline GFR found a reduction of filtration fraction due to decrease in glomerular hyperfiltration [99, 100]. Two other small studies on subjects with mildly or severely impaired renal function observed an increase in eGFR [101] or a decrease in eGFR decline [102]. More recently, a RCT could not demonstrate a difference in the rate of eGFR decline between subjects with OSA and cardiovascular diseases treated by CPAP or under "usual care"; however, the power of the study could be insufficient to demonstrate a difference between the two groups [103]. In a study with a larger number of patients recruited in different sleep laboratories, therapy with fixed CPAP, but not with autoadjusting CPAP, could blunt the spontaneous trend of eGFR to decline over time [104].

In summary, there is some evidence that OSA may worsen kidney function through several mechanisms, and CPAP may exert beneficial effects.

\section{COPD}

Both OSA and chronic obstructive pulmonary disease (COPD) are common and may occur in the same patient. Their association is known as "overlap syndrome" since the early studies [105]. Prevalence of the overlap syndrome has been reported at 1.0 to $3.6 \%$ in the general population, $8-56 \%$ in OSA patients, and $3-66 \%$ in COPD patients [106]. In OSA patients, prevalence of the overlap syndrome was found to increase with age, in agreement with COPD being more prevalent in elderly than middle-aged subjects [106]. In COPD patients, prevalence of respiratory events during sleep was high, with sleep disordered breathing (SDB) in 66\% of patients with moderate to severe COPD [107]. In COPD patients undergoing pulmonary rehabilitation an $\mathrm{AHI} \geq 15 / \mathrm{h}$ was found in $45 \%$ of the sample [108]. COPD patients often show poor sleep quality $[109,110]$ and hypoventilation during sleep [111]. Use of oxygen during sleep could contribute to diagnostic uncertainty regarding OSA [107]. In addition, insufficient data are available on the role of either COPD or OSA severity on the clinical presentation or outcomes of the overlap syndrome, since the consequences of severe OSA associated with mild COPD may differ from those of mild OSA associated with severe COPD.

As outcomes are concerned, early studies reported lower $\mathrm{PaO}_{2}$ and higher $\mathrm{PaCO}_{2}$ in overlap patients compared to OSA patients with a similar AHI, associated with higher pulmonary artery pressure at rest and during exercise [112]. More recent observational studies reported increased mortality in overlap patients compared to OSA patients [113-115], and a protective effect of CPAP treatment $[113,116,117]$. By contrast, a complex study in over 6,000 subjects from the general population recently reported that mortality was higher in patients with $\mathrm{SDB}$ defined as $\mathrm{AHI} \geq 5$, but occurrence of SDB and SDB severity could mitigate the effects of decreasing $\mathrm{FEV}_{1}$ on mortality [118]. These data suggest that OSA and COPD pathophysiology may interact, with low body mass index (BMI) and lung hyperinflation protecting against OSA in COPD, and upper airway and systemic inflammation in COPD potentiating the detrimental effects of OSA [119, 120]. Better phenotypic 
characterization of patients with overlap syndrome is needed, to optimize therapeutic strategies of both diseases.

\section{Asthma}

Asthma and obstructive sleep apnea (OSA) are highly prevalent disorders which are often associated [121]. OSA symptoms are frequent in asthmatic patients [122-126], who also report daytime sleepiness [127], poor asthma control [128-131], and reduced quality of life [132]. Longitudinal data from the Wisconsin Sleep Cohort suggested that asthma at baseline increased the risk to develop OSA during follow up [133].

Sleep studies confirmed that OSA is more common in asthmatics than in controls [134-136], and OSA resulted associated with a higher frequency of asthma exacerbations [136]. Mild-moderate OSA occurred in $49 \%$ of patients with difficult-to-treat asthma [137]. Patients with severe asthma showed increased apnea-hypopnea index (AHI), poor sleep quality and daytime sleepiness [138]. However, lower airway resistance was shown to increase in asthmatic patients during slow wave sleep, whereas upper airway resistance remained low [139]. Moreover, hypopneas rather than apneas were the main type of respiratory events recorded in asthmatic patients [138]. On the other hand, upper airways in patients with OSA and asthma were shown to be smaller than in patients with either disease or controls, suggesting a synergistic role on upper airway inflammation played by both OSA and asthma [140].

In patients with suspected or confirmed OSA, some studies highlighted the association of asthma and obesity, especially in women [141-143]. In the European Sleep Apnea Database (ESADA), OSA and asthma were frequent in obese women [144]. A community-based study in Uppsala reported worse sleep quality and occurrence of nocturnal hypoxemia in women with both OSA and asthma, who showed higher BMI compared to controls or women with either asthma or OSA [145]. Other studies reported a positive relationship between severity of OSA and severity of asthma symptoms [138], higher prevalence of mild-moderate rather than severe OSA in patients with asthma $[135,143]$ or no relationship between asthma and OSA severity [6]. In the ESADA cohort, the distribution of OSA severity was similar in patients with and without physician-diagnosed asthma, and unaffected by treatment for asthma or for gastroesophageal reflux [144]. These differences in results among studies may at least partly reflect variable referral patterns for sleep studies in asthmatic patients, and further studies are needed to better define the real impact of OSA in asthma, and of asthma in OSA.

It is still uncertain whether treatment of OSA with continuous positive airway pressure (CPAP) might improve asthma control or pulmonary function. Some studies reported positive results [146-148] while other studies were negative $[149,150]$. One study reported a decreased rate of $\mathrm{FEV}_{1}$ decline in asthmatic patients treated with CPAP [136], but the majority of studies agree on unchanged pulmonary function after CPAP. A recent systematic review pointed out that results of different studies do not allow to document a definite improvement in asthma control, although a positive effect of CPAP treatment seems to occur in patients with severe OSA or poorly controlled asthma [151].

In summary, the association of asthma and OSA would benefit from careful phenotyping of both diseases. Neutrophilic rather than eosinophilic inflammation was found in asthmatic patients with OSA [137, 152], suggesting a possible contribution of OSA to neutrophilic asthma. Further studies are needed to assess whether CPAP treatment could be a useful adjunct of asthma treatment in OSA patients, especially in cases of poorly controlled asthma.

\section{Cancer}

The association of OSA and cancer has been explored in the last few years. In mice bearing human subcutaneous melanoma xenografts, intermittent hypoxia exposure accelerated tumor progression, and was associated with both metastases and resistance to treatment [153]. Such an effect was possibly mediated by activation of the hypoxia inducible factor (HIF) 1-alpha pathway [153, 154].

Epidemiological and clinical studies have explored the association of OSA and cancer in humans. Cancer mortality during follow up was increased in OSA patients compared to controls in general population samples [155, 156], cohorts of OSA patients [157], and cohorts of cancer patients [158], in association with OSA severity and duration of nocturnal hypoxemia. Some studies however did not show increased mortality associated with occurrence of OSA in the general population [159] or cohorts of cancer patients [160, 161].

Other studies reported increased incidence of cancer in cohorts of OSA patients compared to controls [156, 159, 162-165]; however, two population-based studies were negative [166, 167], but one study assessed only OSA symptoms rather than collecting objective sleep data [166]. According to some reports, incidence of cancer was especially high in relatively young OSA patients [157, 162]. Two studies assessing different cancer localizations reported a high risk of pancreatic cancer and melanoma in OSA patients, whereas risk for colorectal cancer was relatively low compared to nonOSA subjects $[159,160]$. Therefore, although most studies indicate that intermittent hypoxia in OSA may increase cancer risk, firm evidence is still lacking, as confirmed by results of two recent meta-analyses $[168,169]$. 
A series of studies focused on the association of OSA and cutaneous malignant melanoma (CMM), to verify whether data from the mouse model could be confirmed in humans. Tumor aggressiveness was increased in CMM patients with OSA and long time spent at low oxygen saturation (CT90\%) or high oxygen desaturation index (ODI 4\%) [158, 170-173]. Interestingly, tumor aggressiveness was positively associated with expression of the adhesion molecule VCAM-1 [171], HIF-1alpha [173], but not with expression of vascular endothelial growth factor (VEGF) [173]. Similar results were reported in patients with lung cancer and OSA [158].

In summary, the association of OSA and cancer is biologically plausible, as shown by the experimental studies using the intermittent hypoxia model. Human data on incidence of cancer and mortality in OSA patients confirm experimental data, especially in cohorts of CMM patients. However, no definitive evidence is available, and further studies are required especially concerning the possible higher risk of cancer in young OSA patients. Moreover, no study has assessed the potentially protective role of CPAP treatment, and studies based on administrative data often lack adjustments for known risk factors for cancer.

\section{Conclusions}

Comorbidities are frequent in OSA patients, and OSA appears as a potential trigger for worse prognosis by worsening chronic organ damage [174], justifying the hypothesis of a dangerous liaison between OSA and comorbidities. Although the possible protective role of OSA treatment is still uncertain, it could differ among different clinical phenotypes of OSA patients. In that regard, studies are still moving their first steps [18, 175], but some data are available showing different responses depending on OSA phenotype [19]. Such view is confirmed by the recent report developed by European experts on OSA, which suggests that both symptoms and organ damage should be considered when choosing the appropriate treatment for OSA [174]. Although personalized medicine is slowly developing in the OSA field, testing a model similar to the model developed for COPD might provide useful hints on the possible detrimental role of comorbidities in OSA patients and suggest the best therapeutic approaches. Moreover, it is necessary to consider the role of comorbidities in elderly OSA patients and women with OSA, given the differences in pathophysiology and clinical presentation compared to the usual model of middle-aged men that dominates the current literature. Careful assessment of comorbidities should become standard clinical practice for OSA patients.

\section{Abbreviations}

ACS: Acute Coronary Syndromes; AF: Atrial fibrillation; AHI: Apnea-Hypopnea Index; BMI: Body mass index; CMM: Cutaneous malignant melanoma;

COPD: Chronic Obstructive Pulmonary Disease; CPAP: Continuous Positive

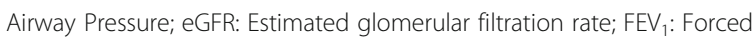
expiratory volume in $1 \mathrm{~s}$; HIF: Hypoxia Inducible Factor; ICD: Implantable cardioverter-defibrillator; MetS: Metabolic syndrome; OSA: Obstructive sleep apnea; $\mathrm{PaO}_{2}$ : Arterial partial pressure of oxygen; $\mathrm{PaCO}_{2}$ : Arterial partial pressure of carbon dioxide; RCTs: Randomized controlled trials; SDB: Sleep Disordered Breathing; UA: Upper airways; VEGF: Endothelial Growth Factor

\begin{abstract}
Acknowledgements
Not applicable.

\section{Funding}

This work has been funded by University of Palermo, Italy, and Institute of Biomedicine and Molecular Immunology (IBIM), National Research Council (CNR), Palermo, Italy. Publication costs of this article will be funded by Novamedia and Italian Respiratory Society (IRS).
\end{abstract}

\section{Availability of data and materials \\ Not applicable.}

\section{Authors' contributions}

MRB conceived the manuscript; $P B, E M$ and $A C$ contributed to reference search; all authors contributed in writing the manuscript. All authors read and approved the final manuscript.

Ethics approval and consent to participate

Not applicable.

Consent for publication

Not applicable.

\section{Competing interests}

The authors declare they have no competing interests.

\section{Publisher's Note}

Springer Nature remains neutral with regard to jurisdictional claims in published maps and institutional affiliations.

\section{Author details \\ ${ }^{1}$ Division of Respiratory Medicine, Biomedical Department of Internal Medicine and Medical Specialties (Di.Bi.M.I.S), University Hospital Paolo Giaccone, University of Palermo, Piazza delle Cliniche, 2, 90100 Palermo, Italy. ${ }^{2}$ National Research Council (CNR), Institute of Biomedicine and Molecular Immunology (IBIM), Palermo, Italy. ${ }^{3}$ Clinic for Pneumology und Allergology, Center of Sleep Medicine and Respiratory Care, Bethanien Hospital, Solingen, Germany.}

Received: 21 November 2018 Accepted: 20 January 2019 Published online: 14 February 2019

\section{References}

1. Lévy P, Kohler M, McNicholas WT, Barbé F, McEvoy RD, Somers VK, Lavie L Pépin JL. Obstructive sleep apnoea syndrome. Nat Rev Dis Primers. 2015;1 15015. https://doi.org/10.1038/nrdp.2015.15.

2. Wolk R, Shamsuzzaman AS, Somers VK. Obesity, sleep apnea, and hypertension. Hypertension. 2003;42:1067-74. https://doi.org/10.1161/01 HYP.0000101686.98973.A3.

3. Mokhlesi B, Ham SA, Gozal D. The effect of sex and age on the comorbidity burden of OSA: an observational analysis from a large nationwide US health claims database. Eur Respir J. 2016;47:1162-9. https://doi.org/10.1183/ 13993003.01618-2015

4. Senaratna CV, English DR, Currier D, Perret JL, Lowe A, Lodge C, Russell M, Sahabandu S, Matheson MC, Hamilton GS, Dharmage SC. Sleep apnoea in Australian men: disease burden, co-morbidities, and correlates from the Australian longitudinal study on male health. BMC Public Health. 2016; 16(Suppl 1):1029. https://doi.org/10.1186/s12889-016-3703-8.

5. Appleton SL, Gill TK, Lang CJ, Taylor AW, McEvoy RD, Stocks NP, González Chica DA, Adams RJ. Prevalence and comorbidity of sleep conditions in Australian adults: 2016 Sleep Health Foundation national survey. Sleep Health. 2018;4:13-9. https://doi.org/10.1016/j.sleh.2017.10.006. 
6. Tveit RL, Lehmann S, Bjorvatn B. Prevalence of several somatic diseases depends on the presence and severity of obstructive sleep apnea. PLoS ONE. 2018;13(2):e0192671. https://doi.org/10.1371/journal.pone.0192671.

7. Heinzer R, Marti-Soler H, Marques-Vidal P, Tobback N, Andries D, Waeber G, Preisig M, Vollenweider P, Haba-Rubio J. Impact of sex and menopausal status on the prevalence, clinical presentation, and comorbidities of sleepdisordered breathing. Sleep Med. 2018;51:29-36. https://doi.org/10.1016/j. sleep.2018.04.016.

8. Robichaud-Hallé L, Beaudry M, Fortin M. Obstructive sleep apnea and multimorbidity. BMC Pulm Med. 2012 Sep 24;12:60. https://doi.org/10.1186/ 1471-2466-12-60.

9. Ruel G, Martin SA, Lévesque JF, Wittert GA, Adams RJ, Appleton SL, Shi Z, Taylor AW. Association between multimorbidity and undiagnosed obstructive sleep apnea severity and their impact on quality of life in men over 40 years old. Glob Health Epidemiol Genom. 2018 Jun 4;3:e10. https:// doi.org/10.1017/gheg.2018.9.

10. Chiang CL, Chen YT, Wang KL, Su W, Wu LA, Perng DW, Chang SC, Chen YM, Chen TJ, Chou KT. Comorbidities and risk of mortality in patients with sleep apnea. Ann Med. 2017;49:377-83. https://doi.org/10.1080/07853890.2017.1282167.

11. Jennum P, Tønnesen P, Ibsen R, Kjellberg J. All-cause mortality from obstructive sleep apnea in male and female patients with and without continuous positive airway pressure treatment: a registry study with 10 years of follow-up. Nat Sci Sleep. 2015;7:43-50. https://doi.org/10.2147/NSS.S75166.

12. Marrone O, Lo Bue A, Salvaggio A, Dardanoni G, Insalaco G. Comorbidities and survival in obstructive sleep apnoea beyond the age of 50. Eur J Clin Invest. 2013;43:27-33. https://doi.org/10.1111/eci.12011.

13. Marotta AM, Borel JC, Galerneau LM, Tamisier R, Bonsignore MR, Pépin JL. Cardiovascular events in moderately to severely obese obstructive sleep apnea patients on positive airway pressure therapy. Respiration. 2017;93: 179-88. https://doi.org/10.1159/000454988.

14. Jennum P, Tønnesen P, Ibsen R, Kjellberg J. Obstructive sleep apnea: effect of comorbidities and positive airway pressure on all-cause mortality. Sleep Med. 2017;36:62-6. https://doi.org/10.1016/j.sleep.2017.04.018.

15. de Batlle J, Bertran S, Turino C, Escarrabill J, Sánchez-de-la-Torre M, Woehrle H, Barbé F. Mortality in patients treated with continuous positive airway pressure at the population level. Am J Respir Crit Care Med. 2018;197:1486148. https://doi.org/10.1164/rccm.201709-1889LE.

16. López-Padilla D, Alonso-Moralejo R, Martínez-García MÁ, De la Torre CS. Díaz de Atauri MJ. Continuous positive airway pressure and survival of very elderly persons with moderate to severe obstructive sleep apnea. Sleep Med. 2016;19:23-9. https://doi.org/10.1016/j.sleep.2015.10.015.

17. Ou Q, Chen Y-C, Zhuo S-Q, Tian X-T, He C-H, Lu X-L, Gao X-L. Continuous positive airway pressure treatment reduces mortality in elderly patients with moderate to severe obstructive severe sleep apnea: a cohort study. PLoS One. 2015;10(6):e0127775. https://doi.org/10.1371/journal.pone.0127775.

18. Bonsignore MR, Suarez Giron MC, Marrone O, Castrogiovanni A, Montserrat JM. Personalised medicine in sleep respiratory disorders: focus on obstructive sleep apnoea diagnosis and treatment. Eur Respir Rev. 2017; 26(146). pii:170069, doi:https://doi.org/10.1183/16000617.0069-2017.

19. Zinchuk AV, Jeon S, Koo BB, Yan X, Bravata DM, Qin L, Selim BJ, Strohl KP, Redeker NS, Concato J, Yaggi HK. Polysomnographic phenotypes and their cardiovascular implications in obstructive sleep apnoea. Thorax. 2018;73: 472-80. https://doi.org/10.1136/thoraxjnl-2017-210431.

20. Aronson D, Lavie L, Lavie P. Does OSA upregulate cardioprotective pathways to an ischemic insult? Chest. 2018;153:295-7. https://doi.org/10. 1016/j.chest.2017.07.036.

21. Lavie L. Oxidative stress in obstructive sleep apnea and intermittent hypoxia--revisited--the bad ugly and good: implications to the heart and brain. Sleep Med Rev. 2015;20:27-45. https://doi.org/10.1016/j.smrv.2014.07.003.

22. Parati G, Lombardi C, Hedner J, Bonsignore MR, Grote L, Tkacova R, Lévy P, Riha R, Bassetti C, Narkiewicz K, Mancia G, WT MN. EU COST Action B26 members. Recommendations for the management of patients with obstructive sleep apnoea and hypertension. Eur Respir J. 2013;41:523-38. https://doi.org/10.1183/09031936.00226711.

23. Marrone $\mathrm{O}$, Bonsignore MR. Blood-pressure variability in patients with obstructive sleep apnea: current perspectives. Nat Sci Sleep. 2018;10:229-42. https://doi.org/10.2147/NSS.S148543.

24. Xia W, Huang $Y$, Peng B, Zhang $X$, Wu Q, Sang Y, Luo $Y$, Liu X, Chen Q, Tian K. Relationship between obstructive sleep apnoea syndrome and essential hypertension: a dose-response meta-analysis. Sleep Med. 2018;47:11-8. https://doi.org/10.1016/j.sleep.2018.03.016.
25. Haentjens P, Van Meerhaeghe A, Moscariello A, De Weerdt S, Poppe K, Dupont A, Velkeniers B. The impact of continuous positive airway pressure on blood pressure in patients with obstructive sleep apnea syndrome: evidence from a meta-analysis of placebo-controlled randomized trials. Arch Intern Med. 2007;167:757-64.

26. Iftikhar $\mathrm{H}$, Valentine $\mathrm{CW}$, Bittencourt LR, Cohen DL, Fedson AC, Gíslason T, Penzel T, Phillips CL, Yu-sheng L, Pack Al, Magalang UJ. Effects of continuous positive airway pressure on blood pressure in patients with resistant hypertension and obstructive sleep apnea: a meta-analysis. J Hypertens. 2014;32:2341-50. https://doi.org/10.1097/HJH.0000000000000372.

27. Khurshid K, Yabes J, Weiss PM, Dharia S, Brown L, Unruh M, Jhamb M. Effect of anti-hypertensive medications on the severity of obstructive sleep apnea: a systematic review and meta-analysis. J Clin Sleep Med. 2016:12:1143-51. https://doi.org/10.5664/jcsm.6054.

28. Pépin JL, Tamisier R, Barone-Rochette G, Launois SH, Lévy P, Baguet JP. Comparison of continuous positive airway pressure and valsartan in hypertensive patients with sleep apnea. Am J Respir Crit Care Med. 2010; 182:954-60. https://doi.org/10.1164/rccm.200912-18030C.

29. Revol B, Jullian-Desayes I, Bailly S, Regnaut L, Tamisier R, Pepin JL, JoyeuxFaure $M$. What is the best treatment strategy for obstructive sleep apnoearelated hypertension? Hypertens Res. 2018 Oct 15. https://doi.org/10.1038/ s41440-018-0114-5.

30. Marin JM, Carrizo SJ, Vicente E, Agusti AG. Long-term cardiovascular outcomes in men with obstructive sleep apnoea-hypopnoea with or without treatment with continuous positive airway pressure: an observational study. Lancet. 2005:365:1046-53.

31. Fu Y, Xia Y, Yi H, Xu H, Guan J, Yin S. Meta-analysis of all-cause and cardiovascular mortality in obstructive sleep apnea with or without continuous positive airway pressure treatment. Sleep Breath. 2017;21:181-9. https://doi.org/10.1007/s11325-016-1393-1.

32. Lee CH, Sethi R, Li R, Ho HH, Hein T, Jim MH, Loo G, Koo CY, Gao XF, Chandra S, Yang XX, Furlan SF, Ge Z, Mundhekar A, Zhang WW, Uchôa CH, Kharwar RB, Chan PF, Chen SL, Chan MY, Richards AM, Tan HC, Ong TH, Roldan G, Tai BC, Drager LF, Zhang JJ. Obstructive sleep apnea and cardiovascular events after percutaneous coronary intervention. Circulation. 2016;133:2008-17. https://doi.org/10.1161/CIRCULATIONAHA.115.019392.

33. Wang X, Fan J-Y, Zhang Y, Nie S-P, Wei Y-X. Association of obstructive sleep apnea with cardiovascular outcomes after percutaneous coronary intervention. A systematic review and meta-analysis. Medicine. 2018; 97(17(e0621)). https://doi.org/10.1097/MD.0000000000010621.

34. Yu J, Zhou Z, McEvoy RD, Anderson CS, Rodgers A, Perkovic V, Neal B. Association of positive airway pressure with cardiovascular events and death in adults with sleep apnea: a systematic review and meta-analysis. JAMA. 2017;318:156-66. https://doi.org/10.1001/jama.2017.7967.

35. Drager LF, McEvoy RD, Barbe F, Lorenzi-Filho G, Redline S. INCOSACT Initiative (International Collaboration of Sleep Apnea Cardiovascular Trialists). Sleep apnea and cardiovascular disease: lessons from recent trials and need for team science. Circulation. 2017;136:1840-50. https://doi.org/10.1161/ CIRCULATIONAHA.117.029400.

36. Martinez-Garcia MA, Campos-Rodriguez F, Javaheri S, Gozal D. Pro: continuous positive airway pressure and cardiovascular prevention. Eur Respir J. 2018; 51.pii: 1702400. doi: https://doi.org/10.1183/13993003.02400-2017.

37. McEvoy RD, Kohler M. Con: continuous positive airway pressure and cardiovascular prevention. Eur Respir J 2018; 51. pii: 1702721. doi: https:// doi.org/10.1183/13993003.02721-2017.

38. Khan SU, Duran CA, Rahman H, Lekkala M, Saleem MA, Kaluski E. A metaanalysis of continuous positive airway pressure therapy in prevention of cardiovascular events in patients with obstructive sleep apnoea. Eur Heart J. 2018;39:2291-7. https://doi.org/10.1093/eurheartj/ehx597.

39. Huang Z, Zheng Z, Luo Y, Li S, Zhu J, Liu J. Prevalence of sleep-disordered breathing in acute coronary syndrome: a systemic review and meta-analysis. Sleep Breath. 2017;21:217-26. https://doi.org/10.1007/s11325-016-1398-9.

40. Esquinas C, Sánchez-de-la Torre M, Aldomá A, Florés M, Martínez M, Barceló A, Barbé F. Spanish Sleep Network. Rationale and methodology of the impact of continuous positive airway pressure on patients with ACS and nonsleepy OSA: the ISAACC Trial. Clin Cardiol. 2013;36:495-501. https://doi. org/10.1002/clc.22166.

41. Deng F, Raza A, Guo J. Treating obstructive sleep apnea with continuous positive airway pressure reduces risk of recurrent atrial fibrillation after catheter ablation: a meta-analysis. Sleep Med. 2018 Jun;46:5-11. https://doi. org/10.1016/j.sleep.2018.02.013. 
42. Congrete S, Bintvihok M, Thongprayoon C, Bathini T, Boonpheng B, Sharma K, Chokesuwattanaskul R, Srivali N, Tanawuttiwat T, Cheungpasitporn W. Effect of obstructive sleep apnea and its treatment of atrial fibrillation recurrence after radiofrequency catheter ablation: A meta-analysis. J Evid Based Med. 2018;11:145-51. https://doi.org/10.1111/jebm.12313.

43. Raghuram A, Clay R, Kumbam A, Tereshchenko LG, Khan A. A systematic review of the association between obstructive sleep apnea and ventricular arrhythmias. J Clin Sleep Med. 2014;10((10)):1155-60. https://doi.org/10.5664/jcsm.4126.

44. Gami AS, Olson EJ, Shen WK, Wright RS, Ballman KV, Hodge DO, Herges RM, Howard DE, Somers VK. Obstructive sleep apnea and the risk of sudden cardiac death: a longitudinal study of 10,701 adults. J Am Coll Cardiol. 2013; 62:610-6. https://doi.org/10.1016/j.jacc.2013.04.080

45. Martins EF, Martinez D, da Silva FABS, Sezerá L, da Rosa de Camargo R, Fiori CZ, Fuchs FD, Moraes RS. Disrupted day-night pattern of cardiovascular death in obstructive sleep apnea. Sleep Med. 2017;38:144-50. https://doi. org/10.1016/j.sleep.2017.06.027.

46. Mansukhani MP, Wang S, Somers VK. Sleep, death, and the heart. Am J Physiol Heart Circ Physiol. 2015;309:H739-49. https://doi.org/10.1152/ ajpheart.00285.2015.

47. Bitter T, Westerheide N, Prinz C, Hossain MS, Vogt J, Langer C, Horstkotte D, Oldenburg O. Cheyne-Stokes respiration and obstructive sleep apnoea are independent risk factors for malignant ventricular arrhythmias requiring appropriate cardioverter-defibrillator therapies in patients with congestive heart failure. Eur Heart J. 2011 Jan;32(1):61-74. https://doi.org/10.1093/ eurheartj/ehq327.

48. Fox H, Bitter T, Horstkotte D, Oldenburg O. Sleep-disordered breathing and arrhythmia in heart failure patients. Sleep Med Clin. 2017;12(2):229-41. https://doi.org/10.1016/j.jsmc.2017.01.003.

49. Li M, Li K, Zhang X-W, Hou W-S, Tang Z-Y. Habitual snoring and risk of stroke: a meta-analysis of prospective studies. Int J Cardiol. 2015;185:46-9. https://doi.org/10.1016/j.ijcard.2015.03.112.

50. Li M, Hou W-S, Zhang X-W, Tang Z-Y. Obstructive sleep apnea and risk of stroke: a meta-analysis of prospective studies. Int J Cardiol. 2014;172(2):4669. https://doi.org/10.1016/j.ijcard.2013.12.230.

51. Kim Y, Koo YS, Lee HY, Lee S-Y. Can continuous positive airway pressure reduce the risk of stroke in obstructive sleep apnea patients? A systematic review and meta-analysis. PLoS ONE. 2016;11(1):e0146317. https://doi.org/10. 1371/journal.pone.0146317.

52. Brill AK, Horvath T, Seiler A, Camilo M, Haynes AG, Ott SR, Egger M, Bassetti CL. CPAP as treatment of sleep apnea after stroke: A meta-analysis of randomized trials. Neurology. 2018;90:e1222-30. https://doi.org/10.1212/ WNL.0000000000005262.

53. Schenk S, Saberi M, Olefsky JM. Insulin sensitivity: modulation by nutrients and inflammation. J. Clin. Invest. 2008;118:2992-3002. https://doi.org/10. $1172 / \mathrm{JCl} 34260$.

54. Anothaisintawee T, Reutrakul S, Van Cauter E, Thakkinstian A. Sleep disturbances compared to traditional risk factors for diabetes development: Systematic review and meta-analysis. Sleep Med Rev. 2016 Dec;30:11-24. https://doi.org/10.1016/j.smrv.2015.10.002.

55. Ong CW, O'Driscoll DM, Truby H, Naughton MT, Hamilton GS. The reciprocal interaction between obesity and obstructive sleep apnoea. Sleep Med Rev. 2013;17:123-31. https://doi.org/10.1016/j.smrv.2012.05.002.

56. Aurora RN, Punjabi NM. Obstructive sleep apnoea and type 2 diabetes mellitus: a bidirectional association. Lancet Respir Med. 2013;1:329-38. https://doi.org/10.1016/S2213-2600(13)70039-0.

57. Alberti KG, Eckel RH, Grundy SM, Zimmet PZ, Cleeman Jl, Donato KA, Fruchart JC, James WP, Loria CM, Smith SC Jr. International Diabetes Federation Task Force on Epidemiology and Prevention; Hational Heart, Lung, and Blood Institute; American Heart Association; World Heart Federation; International Atherosclerosis Society; International Association for the Study of Obesity. Harmonizing the metabolic syndrome: a joint interim statement of the International Diabetes Federation Task Force on Epidemiology and Prevention; National Heart, Lung, and Blood Institute; American Heart Association; World Heart Federation; International Atherosclerosis Society; and International Association for the Study of Obesity. Circulation. 2009;120(16):1640-5. https://doi.org/10.1161/ CIRCULATIONAHA.109.192644.

58. Xu S, Wan Y, Xu M, Ming J, Xing Y, An F, Ji Q. The association between obstructive sleep apnea and metabolic syndrome: a systematic review and meta-analysis. BMC Pulm Med. 2015;15:105. https://doi.org/10.1186/s12890015-0102-3
59. Gaines J, Vgontzas AN, Fernandez-Mendoza J, Bixler EO. Obstructive sleep apnea and the metabolic syndrome: The road to clinically-meaningful phenotyping, improved prognosis, and personalized treatment. Sleep Med Rev. 2018:42:211-9. https://doi.org/10.1016/j.smrv.2018.08.009.

60. liyori N, Alonso LC, Li J, Sanders MH, Garcia-Ocana A, O'Doherty RM, Polotsky W, O'Donnell CP. Intermittent hypoxia causes insulin resistance in lean mice independent of autonomic activity. Am J Respir Crit Care Med. 2007;175:851-7. https://doi.org/10.1164/rccm.200610-15270C.

61. Louis M, Punjabi NM. Effects of acute intermittent hypoxia on glucose metabolism in awake healthy volunteers. J Appl Physiol. 2009;106:1538-44. https://doi.org/10.1152/japplphysiol.91523.2008.

62. Baud MO, Magistretti PJ, Petit JM. Sustained sleep fragmentation affects brain temperature, food intake and glucose tolerance in mice. J Sleep Res. 2013;22:3-12. https://doi.org/10.1111/j.1365-2869.2012.01029.x.

63. Hakim F, Wang Y, Carreras A, Hirotsu C, Zhang J, Peris E, Gozal D. Chronic sleep fragmentation during the sleep period induces hypothalamic endoplasmic reticulum stress and PTP1b-mediated leptin resistance in male mice. Sleep. 2015;38:31-40. https://doi.org/10.5665/sleep.4320.

64. Zou J, Xia Y, Xu H, Fu Y, Qian Y, Li X, Zhao X, Zou J, Meng L, Liu S, Zhu $\mathrm{H}, \mathrm{Yi}$ H, Guan J, Chen B, Yin S. Independent relationships between cardinal features of obstructive sleep apnea and glycometabolism: a cross-sectional study. Metabolism. 2018;85:340-7. https://doi.org/10. 1016/j.metabol.2017.11.021

65. Moreno-Indias I, Torres M, Montserrat JM, Sanchez-Alcoholado L, Cardona F, Tinahones FJ, Gozal D, Poroyko VA, Navajas D, Queipo-Ortuño MI, Farré R. Intermittent hypoxia alters gut microbiota diversity in a mouse model of sleep apnoea. Eur Respir J. 2015;45:1055-65. https://doi.org/10.1183/ 09031936.00184314.

66. Tripathi A, Melnik AV, Xue J, Poulsen O, Meehan MJ, Humphrey G, Jiang L, Ackermann G, McDonald D, Zhou D, Knight R, Dorrestein PC, Haddad GG. Intermittent hypoxia and hypercapnia, a hallmark of obstructive sleep apnea, alters the gut microbiome and metabolome. mSystems. 2018; 3(3). pii: e00020-e00018. doi: https://doi.org/10.1128/mSystems.00020-18.

67. Poroyko VA, Carreras A, Khalyfa A, Khalyfa AA, Leone V, Peris E, Almendros I, Gileles-Hillel A, Qiao Z, Hubert N, Farré R, Chang EB, Gozal D. Chronic sleep disruption alters gut microbiota, induces systemic and adipose tissue inflammation and insulin resistance in mice. Sci Rep. 2016;6:35405. https:// doi.org/10.1038/srep35405.

68. Bonsignore MR, McNicholas WT, Montserrat JM, Eckel J. Adipose tissue in obesity and obstructive sleep apnoea. Eur Respir J. 2012;39(3):746-67. https://doi.org/10.1183/09031936.00047010.

69. Lam JC, Mak JC, Ip MS. Obesity, obstructive sleep apnoea and metabolic syndrome. Respirology. 2012;17:223-36. https://doi.org/10.1111/j.1440-1843. 2011.02081.x.

70. Gozal D, Gileles-Hillel A, Cortese R, Li Y, Almendros I, Qiao Z, Khalyfa AA Andrade J, Khalyfa A. Visceral white adipose tissue after chronic intermittent and sustained hypoxia in mice. Am J Respir Cell Mol Biol. 2017;56:477-87. https://doi.org/10.1165/rcmb.2016-02430C.

71. Ryan S. Adipose tissue inflammation by intermittent hypoxia: mechanistic link between obstructive sleep apnoea and metabolic dysfunction. J Physiol. 2017;595:2423-30. https://doi.org/10.1113/JP273312.

72. Hoyos CM, Killick R, Yee BJ, Phillips CL, Grunstein RR, Liu PY. Cardiometabolic changes after continuous positive airway pressure for obstructive sleep apnoea: a randomised sham-controlled study. Thorax. 2012;67:1081-9. https://doi.org/10.1136/thoraxjnl-2011-201420.

73. Sivam S, Phillips CL, Trenell MI, Yee BJ, Liu PY, Wong KK, Grunstein RR. Effects of 8 weeks of continuous positive airway pressure on abdominal adiposity in obstructive sleep apnoea. Eur Respir J. 2012;40:913-8. https:// doi.org/10.1183/09031936.00177011.

74. Chirinos JA, Gurubhagavatula I, Teff K, Rader DJ, Wadden TA, Townsend R, Foster GD, Maislin G, Saif H, Broderick P, Chittams J, Hanlon AL, Pack Al. CPAP, weight loss, or both for obstructive sleep apnea. N Engl J Med. 2014; 370:2265-75. https://doi.org/10.1056/NEJMoa1306187.

75. Pamidi S, Wroblewski K, Stepien M, Sharif-Sidi K, Kilkus J, Whitmore H, Tasali E. Eight hours of nightly continuous positive airway pressure treatment of obstructive sleep apnea improves glucose metabolism in patients with prediabetes. A randomized controlled trial. Am J Respir Crit Care Med. 2015; 192:96-105. https://doi.org/10.1164/rccm.201408-15640C.

76. Conde SV, Sacramento JF, Guarino MP, Gonzalez C, Obeso A, Diogo LN, Monteiro EC, Ribeiro MJ. Carotid body, insulin, and metabolic diseases: unraveling the links. Front Physiol. 2014;5:418. https://doi.org/10.3389/fphys.2014.00418. 
77. Reutrakul S, Mokhlesi B. Obstructive Sleep Apnea and Diabetes: A State of the Art Review. Chest. 2017;152:1070-86. https://doi.org/10.1016/j.chest.2017.05.009.

78. Zhu B, Ma C, Chaiard J, Shi C. Effect of continuous positive airway pressure on glucose metabolism in adults with type 2 diabetes: a systematic review and meta-analysis of randomized controlled trials. Sleep Breath. 2018;22: 287-95. https://doi.org/10.1007/s11325-017-1554-x.

79. Labarca G, Reyes T, Jorquera J, Dreyse J, Drake L. CPAP in patients with obstructive sleep apnea and type 2 diabetes mellitus: Systematic review and meta-analysis. Clin Respir J. 2018;12:2361-8. https:/doi.org/10.1111/crj.12915.

80. Tahrani AA, Ali A, Raymond NT, Begum S, Dubb K, Mughal S, Jose B, Piya MK, Barnett AH, Stevens MJ. Obstructive sleep apnea and diabetic neuropathy: a novel association in patients with type 2 diabetes. Am J Respir Crit Care Med. 2012;186:434-41. https://doi.org/10.1164/rccm.201112-21350C.

81. Stadler S, Jalili S, Schreib A, Jung B, Zeman F, Böger CA, Heid IM, Arzt M. DIACORE study group. Association of sleep-disordered breathing with severe chronic vascular disease in patients with type 2 diabetes. Sleep Med. 2018;48:53-60. https://doi.org/10.1016/j.sleep.2018.05.001.

82. Altaf QA, Dodson P, Ali A, Raymond NT, Wharton H, Fellows H, HampshireBancroft R, Shah M, Shepherd E, Miah J, Barnett AH, Tahrani AA. Obstructive sleep apnea and retinopathy in patients with type 2 diabetes. A longitudinal study. Am J Respir Crit Care Med. 2017;196:892-900. https://doi. org/10.1164/rccm.201701-01750C

83. Leong WB, Banerjee D, Nolen M, Adab P, Thomas GN, Taheri S. Hypoxemia and glycemic control in type 2 diabetes mellitus with extreme obesity. J Clin Endocrinol Metab. 2014;99:E1650-4. https://doi.org/10.1210/jc.2014-1260.

84. Leong WB, Jadhakhan F, Taheri S, Thomas GN, Adab P. The Association between Obstructive Sleep Apnea on Diabetic Kidney Disease: A Systematic Review and Meta-Analysis. Sleep. 2016;39:301-8. https://doi.org/10.5665/sleep.5432.

85. Nishimura A, Kasai T, Kikuno S, Nagasawa K, Okubo M, Narui K, Mori Y. Effect of sleep-disordered breathing on albuminuria in 273 patients with type 2 diabetes. J Clin Sleep Med. 2018;14:401-7. doi.org/10.5664/jcsm.6986.

86. Liguori C, Placidi F, Palmieri MG, Izzi F, Ludovisi R, Mercuri NB, Pierantozzi M. Continuous positive airway pressure treatment may improve optic nerve function in obstructive sleep apnea: an electrophysiological study. J Clin Sleep Med. 2018;14:953-8. https://doi.org/10.5664/jcsm.7158.

87. Quan W, Zheng D, McEvoy RD, Barbe F, Chen R, Liu Z, et al. High risk characteristics for recurrent cardiovascular events among patients with obstructive sleep apnoea in the SAVE study. EClinicalMedicine. 2018;2(3):59-65.

88. Borel A-L, Tamisier R, Böhme P, Priou P, Avignon A, Benhamou P-Y, Hanaire $H$, Pépin J-L, Kessler L, Valensi P, Darmon P, Gagnadoux F. Obstructive sleep apnoea syndrome in patients living with diabetes: Which patients should be screened? Diabetes Metab. 2018. pii: S1262-3636(18)30163-0. doi.org/10. 1016/j.diabet.2018.08.006

89. Abuyassin B, Sharma K, Ayas NT, Laher I. Obstructive Sleep Apnea and Kidney Disease: A Potential Bidirectional Relationship? J Clin Sleep Med. 2015;11:915-24. https://doi.org/10.5664/jcsm.4946.

90. Zalucky AA, Nicholl DD, Hanly PJ, Poulin MJ, Turin TC, Walji S, Handley GB, Raneri JK, Sola DY, Ahmed SB. Nocturnal hypoxemia severity and reninangiotensin system activity in obstructive sleep apnea. Am J Respir Crit Care Med. 2015;192:873-80. https://doi.org/10.1164/rccm.201502-03830C.

91. Marrone O, Battaglia S, Steiropoulos P, Basoglu OK, Kvamme JA, Ryan S, Pepin JL, Verbraecken J, Grote L, Hedner J, Bonsignore MR. ESADA study group. Chronic kidney disease in European patients with obstructive sleep apnea: the ESADA cohort study. J Sleep Res. 2016;25(6):739-45. https://doi. org/10.1111/jsr.12426.

92. Adams RJ, Appleton SL, Vakulin A, Hanly PJ, McDonald SP, Martin SA, Lang CJ, Taylor AW, McEvoy RD, Antic NA, Catcheside PG, Vincent AD, Wittert GA Chronic kidney disease and sleep apnea association of kidney disease with obstructive sleep apnea in a population study of men. Sleep. 2017:40(1). https://doi.org/10.1093/sleep/zsw015.

93. Molnar MZ, Mucsi I, Novak M, Szabo Z, Freire AX, Huch KM, Arah OA, Ma JZ, Lu JL, Sim JJ, Streja E, Kalantar-Zadeh K, Kovesdy CP. Association of incident obstructive sleep apnoea with outcomes in a large cohort of US veterans. Thorax. 2015;70:888-95. https://doi.org/10.1136/thoraxjnl-2015-206970.

94. Lee YC, Hung SY, Wang HK, Lin CW, Wang HH, Chen SW, Chang MY, Ho LC, Chen YT, Liou HH, Tsai TC, Tseng SH, Wang WM, Lin SH, Chiou YY. Sleep apnea and the risk of chronic kidney disease: A nationwide population-based cohort study. Sleep. 2015;38:213-21. https://doi.org/10.5665/sleep.4400.

95. Chu H, Shih CJ, Ou SM, Chou KT, Lo YH, Chen YT. Association of sleep apnoea with chronic kidney disease in a large cohort from Taiwan. Respirology. 2016;21:754-60.
96. Lin YS, Liu PH, Lin SW, Chuang LP, Ho WJ, Chou YT, Juan KC, Lo MT, Chu $\mathrm{PH}$, Chen NH. Simple obstructive sleep apnea patients without hypertension or diabetes accelerate kidney dysfunction: a population follow-up cohort study from Taiwan. Sleep Breath. 2017;21:85-91. https://doi.org/10.1007/ s11325-016-1376-2.

97. Ahmed SB, Ronksley PE, Hemmelgarn BR, Tsai WH, Manns BJ, Tonelli M, Klarenbach SW, Chin R, Clement FM, Hanly PJ. Nocturnal hypoxia and loss of kidney function. PLoS One. 2011;6(4):e19029. https://doi.org/10.1371/ journal.pone.0019029.

98. Canales MT, Hagen EW, Barnet JH, Peppard PE, Derose SF. Sleep apnea and kidney function trajectory: results from a 20-year longitudinal study of healthy middle-aged adults. Sleep. 2018 Jan;1:41(1). https://doi.org/10.1093/sleep/zsx181.

99. Kinebuchi S, Kazama JJ, Satoh M, Sakai K, Nakayama H, Yoshizawa H, Narita I, Suzuki E, Gejyo F. Short-term use of continuous positive airway pressure ameliorates glomerular hyperfiltration in patients with obstructive sleep apnoea syndrome. Clin Sci (Lond). 2004 Sep;107(3):317-22.

100. Nicholl DD, Hanly PJ, Poulin MJ, Handley GB, Hemmelgarn BR, Sola DY, Ahmed SB. Evaluation of continuous positive airway pressure therapy on reninangiotensin system activity in obstructive sleep apnea. Am J Respir Crit Care Med. 2014;190:572-80. https://doi.org/10.1164/rccm.201403-05260C.

101. Koga S, Ikeda S, Yasunaga T, Nakata T, Maemura K. Effects of nasal continuous positive airway pressure on the glomerular filtration rate in patients with obstructive sleep apnea syndrome. Intern Med. 2013;52(3):345-9.

102. Puckrin R, lqbal S, Zidulka A, Vasilevsky M, Barre P. Renoprotective effects of continuous positive airway pressure in chronic kidney disease patients with sleep apnea. Int Urol Nephrol. 2015;47(11):1839-45.

103. Loffler KA, Heeley E, Freed R, Anderson CS, Brockway B, Corbett A, Chang CL, Douglas JA, Ferrier K, Graham N, Hamilton GS, Hlavac M, McArdle N, McLachlan J, Mukherjee S, Naughton MT, Thien F, Young A, Grunstein RR, Palmer $\sqcup$, Woodman RJ, Hanly PJ. McEvoy RD; SAVE (Sleep Apnea Cardiovascular Endpoints) Investigators. Effect of obstructive sleep apnea treatment on renal function in patients with cardiovascular disease. Am J Respir Crit Care Med. 2017; 196:1456-62. https://doi.org/10.1164/rccm.201703-06030C.

104. Marrone O, Cibella F, Pépin JL, Grote L, Verbraecken J, Saaresranta T, Kvamme JA, Basoglu OK, Lombardi C, McNicholas WT, Hedner J. Bonsignore MR; ESADA Network. Fixed but not autoadjusting positive airway pressure attenuates the time-dependent decline in glomerular filtration rate in patients with OSA. Chest. 2018;154(2):326-34. https://doi.org/10.1016/j.chest.2018.04.020.

105. Flenley DC. Sleep in chronic obstructive lung disease. Clin Chest Med. 1985; 6(4):651-61.

106. Shawon MS, Perret JL, Senaratna CV, Lodge C, Hamilton GS, Dharmage SC. Current evidence on prevalence and clinical outcomes of co-morbid obstructive sleep apnea and chronic obstructive pulmonary disease: A systematic review. Sleep Med Rev. 2017 Apr;32:58-68. https://doi.org/10. 1016/j.smrv.2016.02.007.

107. Soler X, Gaio E, Powell FL, Ramsdell JW, Loredo JS, Malhotra A, Ries AL. High prevalence of obstructive sleep apnea in patients with moderate to severe chronic obstructive pulmonary disease. Ann Am Thorac Soc. 2015 Aug;12(8): 1219-25. https://doi.org/10.1513/AnnalsATS.201407-3360C.

108. Schreiber A, Cemmi F, Ambrosino N, Ceriana P, Lastoria C, Carlucci A. Prevalence and predictors of obstructive sleep apnea in patients with chronic obstructive pulmonary disease undergoing inpatient pulmonary rehabilitation. COPD. 2018 Sep;21:1-6. https://doi.org/10.1080/15412555.2018.1500533.

109. Agusti A, Hedner J, Marin JM, Barbé F, Cazzola M, Rennard S. Night-time symptoms: a forgotten dimension of COPD. Eur Respir Rev. 2011;20:183-94. https://doi.org/10.1183/09059180.00004311.

110. Geiger-Brown J, Lindberg S, Krachman S, McEvoy CE, Criner GJ, Connett JE, Albert RK, Scharf SM. Self-reported sleep quality and acute exacerbations of chronic obstructive pulmonary disease. Int J Chron Obstruct Pulmon Dis. 2015;10:389-97. https://doi.org/10.2147/COPD.S75840.

111. Toraldo DM, Nicolardi G, De Nuccio F, Lorenzo R, Ambrosino N. Pattern of variables describing desaturator COPD patients, as revealed by cluster analysis. Chest. 2005;128:3828-37. https://doi.org/10.1378/chest.128.6.3828.

112. Chaouat A, Weitzenblum E, Krieger J, Ifoundza T, Oswald M, Kessler R. Association of chronic obstructive pulmonary disease and sleep apnea syndrome. Am J Respir Crit Care Med. 1995;151:82-6. https://doi.org/10. 1164/ajrccm.151.1.7812577.

113. Marin JM, Soriano JB, Carrizo SJ, Boldova A, Celli BR. Outcomes in patients with chronic obstructive pulmonary disease and obstructive sleep apnea: the overlap syndrome. Am J Respir Crit Care Med. 2010;182:325-31. https:// doi.org/10.1164/rccm.200912-18690C. 
114. Kendzerska T, Leung RS, Aaron SD, Ayas N, Sandoz JS, Gershon AS. Canadian Respiratory Research Network. Cardiovascular outcomes and all-cause mortality in patients with obstructive sleep apnea and chronic obstructive pulmonary disease (overlap syndrome). Ann Am Thorac Soc. 2018. https://doi.org/10.1513/ AnnalsATS.201802-1360C.

115. Du W, Liu J, Zhou J, Ye D, OuYang Y, Deng Q. Obstructive sleep apnea, COPD, the overlap syndrome, and mortality: results from the 2005-2008 National Health and Nutrition Examination Survey. Int J Chron Obstruct Pulmon Dis. 2018;13:665-74. https://doi.org/10.2147/COPD.S148735.

116. Machado MC, Vollmer WM, Togeiro SM, Bilderback AL, Oliveira MV, Leitão FS, Queiroga F Jr, Lorenzi-Filho G, Krishnan JA. CPAP and survival in moderate-tosevere obstructive sleep apnoea syndrome and hypoxaemic COPD. Eur Respir J. 2010;35:132-7. https://doi.org/10.1183/09031936.00192008.

117. Stanchina ML, Welicky LM, Donat W, Lee D, Corrao W, Malhotra A. Impact of CPAP use and age on mortality in patients with combined COPD and obstructive sleep apnea: the overlap syndrome. J Clin Sleep Med. 2013;9: 767-72. https://doi.org/10.5664/jcsm.2916.

118. Putcha N, Crainiceanu C, Norato G, Samet J, Quan SF, Gottlieb DJ, Redline S, Punjabi NM. Influence of lung function and sleep-disordered breathing on all-cause mortality. A community-based study. Am J Respir Crit Care Med. 2016;194:1007-14. https://doi.org/10.1164/rccm.201511-21780C

119. McNicholas WT. COPD-OSA Overlap Syndrome: Evolving evidence regarding epidemiology, clinical consequences, and management. Chest. 2017;152: 1318-26. https://doi.org/10.1016/j.chest.2017.04.160.

120. Budhiraja R, Siddiqi TA, Quan SF. Sleep disorders in chronic obstructive pulmonary disease: etiology, impact, and management. J Clin Sleep Med. 2015;11:259-70. https://doi.org/10.5664/jcsm.4540.

121. Kong DL, Qin Z, Shen H, Jin HY, Wang W, Wang ZF. Association of obstructive sleep apnea with asthma: a meta-analysis. Sci Rep. 2017;7:4088. https://doi.org/10.1038/s41598-017-04446-6.

122. Larsson $L-G$, Lindberg A, Franklin KA, Lundbäck B. Symptoms related to obstructive sleep apnoea are common in subjects with asthma, chronic bronchitis and rhinitis in a general population. Respir Med. 2001;95:423-9. https://doi.org/10.1159/000050506.

123. Teodorescu M, Consens FB, Bria WF, Coffey MJ, McMorris MS, Weatherwax KJ, Palmisano J, Senger CM, Ye Y, Kalbfleisch JD, Chervin RD. Predictors of habitual snoring and obstructive sleep apnea risk in patients with asthma. Chest. 2009;135:1125-32. https://doi.org/10.1378/ chest.08-1273.

124. Emilsson Öl, Bengtsson A, Franklin KA, Torén K, Benediktsdóttir B, Farkhooy A, Weyler J, Dom S, De Backer W, Gislason T, Janson C. Nocturnal gastrooesophageal reflux, asthma and symptoms of OSA: a longitudinal, general population study. Eur Respir J. 2013;41:1347-54. https://doi.org/10.1183/ 09031936.00052512.

125. Shen TC, Lin CL, Wei CC, Chen CH, Tu CY, Hsia TC, Shih CM, Hsu WH, Sung FC, Kao CH. Risk of obstructive sleep apnea in adult patients with asthma: a population-based cohort study in Taiwan. PLoS One. 2015;10:e0128461. https://doi.org/10.1371/journal.pone.0128461.

126. Jonassen TM, Eagan TM, Bjorvatn B, Lehmann S. Association between obstructive lung disease and symptoms of obstructive sleep apnea in a general population. Clin Respir J. 2016;12:31-9. https:/doi.org/10.1111/cri.12472.

127. Teodorescu M, Consens FB, Bria WF, Coffey MJ, McMorris MS, Weatherwax KJ, Durance A, Palmisano J, Senger CM, Chervin RD. Correlates of daytime sleepiness in patients with asthma. Sleep Med. 2006;7:607-13.

128. Teodorescu M, Polomis DA, Hall SV, Teodorescu MC, Gangnon RE, Peterson AG, Xie A, Sorkness CA, Jarjour NN. Association of obstructive sleep apnea risk with asthma control in adults. Chest. 2010;138:543-50. https://doi.org/ 10.1378/chest.09-3066.

129. Dixon AE, Pratley RE, Forgione PM, Kaminsky DA, Whittaker-Leclair LA, Griffes LA, Garudathri J, Raymond D, Poynter ME, Bunn JY, Irvin CG. Effects of obesity and bariatric surgery on airway hyperresponsiveness, asthma control, and inflammation. J Allergy Clin Immunol. 2011;128:508-15. https:// doi.org/10.1016/j.jaci.2011.06.009.

130. Luyster FS, Teodorescu M, Bleecker E, Busse W, Calhoun W, Castro M, Chung KF, Erzurum S, Israel E, Strollo PJ, Wenzel SE. Sleep quality and asthma control and quality of life in non-severe and severe asthma. Sleep Breath. 2012;16:1129-37. https://doi.org/10.1007/s11325-011-0616-8.

131. Teodorescu M, Polomis DA, Gangnon RE, Fedie JE, Consens FB, Chervin RD, Teodorescu MC. Asthma control and its relationship with obstructive sleep apnea (OSA) in older adults. Sleep Disord. 2013;2013:251567. https://doi.org/ $10.1155 / 2013 / 251567$.
132. Kim MY, Jo EJ, Kang SY, Chang YS, Yoon IY, Cho SH, Min KU, Kim SH. Obstructive sleep apnea is associated with reduced quality of life in adult patients with asthma. Ann Allergy Asthma Immunol. 2013;110:253-7. https://doi.org/10.1016/j.anai.2013.01.005.

133. Teodorescu M, Barnet JH, Hagen EW, Palta M, Young TB, Peppard PE. Association between asthma and risk of developing obstructive sleep apnea. JAMA. 2015;313:156-64. https://doi.org/10.1001/jama.2014.17822.

134. Byun MK, Park SC, Chang YS, Kim YS, Kim SK, Kim HJ, Chang J, Ahn CM, Park MS. Associations of moderate to severe asthma with obstructive sleep apnea. Yonsei Med J. 2013;54:942-8. https://doi.org/10.3349/ymj.2013.54.4.942.

135. Madama D, Silva A, Matos MJ. Overlap syndrome --asthma and obstructive sleep apnea. Rev Port Pneumol. 2016;22:6-10. https://doi.org/10.1016/j. rppnen.2015.08.005.

136. Wang Y, Liu K, Hu K, Yang J, Li Z, Nie M, Dong Y, Huang H, Chen J. Impact of obstructive sleep apnea on severe asthma exacerbations. Sleep Med. 2016;26:1-5. https://doi.org/10.1016/j.sleep.2016.06.013.

137. Taillé C, Rouvel-Tallec A, Stoica M, Danel C, Dehoux M, Marin-Esteban V, Pretolani M, Aubier M, d'Ortho MP. Obstructive sleep apnoea modulates airway inflammation and remodelling in severe asthma. PLoS One. 2016;11: e0150042. https://doi.org/10.1371/journal.pone.0150042.

138. Julien JY, Martin JG, Ernst P, Olivenstein R, Hamid Q, Lemiere C, Pepe C, Naor N, Olha A, Kimoff RJ. Prevalence of obstructive sleep apnea-hypopnea in severe versus moderate asthma. J Allergy Clin Immunol. 2009;124:371-6. https://doi.org/10.1016/j.jaci.2009.05.016

139. Bellia V, Cuttitta G, Insalaco G, Visconti A, Bonsignore G. Relationship of nocturnal bronchoconstriction to sleep stages. Am Rev Respir Dis. 1989;140: 363-7. https://doi.org/10.1164/ajrccm/140.2.363.

140. Dultra FKAA, Tavares A, Dultra JA, Salles C, Crusoé-Rebelo IM, Barbosa I, Souza-Machado A. Pharyngeal airspace of asthmatic individuals and those suffering from obstructive sleep apnea syndrome: Study by CBCT. Eur J Radiol. 2017;95:342-8. https://doi.org/10.1016/j.ejrad.2017.09.002.

141. Alotair H, BaHammam A. Gender differences in Saudi Arabia patients with obstructive sleep apnea. Sleep Breath. 2008;12:323-9. https://doi.org/10. 1007/s11325-008-0184-8

142. Alharbi M, Almutairi A, Alotaibi D, Alotaibi A, Shaikh S, BaHamman AS. The prevalence of asthma in patients with obstructive sleep apnoea. Primary Care Respir J. 2009;18:328-30. https://doi.org/10.4104/pcrj.2009.00020.

143. Greenberg-Dotan S, Reuveni H, Tal A, Oksenberg A, Cohen A, Shaya FT, Tarasiuk A, Scharf SM. Increased prevalence of obstructive lung disease in patients with obstructive sleep apnea. Sleep Breath. 2014;18:69-75. https:// doi.org/10.1007/s11325-013-0850-3.

144. Bonsignore MR, Pepin JL, Anttalainen U, Schiza SE, Basoglu OK, Pataka A, Steiropoulos P, Dogas Z, Grote L, Hedner J, McNicholas WT, Marrone O, ESADA Study Group. Clinical presentation of patients with suspected obstructive sleep apnea and self-reported physician-diagnosed asthma in the ESADA cohort. J Sleep Res. 2018:e12729. https://doi.org/10.1111/jsr.12729.

145. Sundbom F, Janson C, Malinovschi A, Lindberg E. Effects of Coexisting Asthma and Obstructive Sleep Apnea on Sleep Architecture, Oxygen Saturation, and Systemic Inflammation in Women. J Clin Sleep Med. 2018; 14:253-9. https://doi.org/10.5664/jcsm.6946.

146. Ciftci TU, Ciftci B, Guven SF, Kokturk O, Turktas H. Effect of nasal continuous positive airway pressure in uncontrolled nocturnal asthmatic patients with obstructive sleep apnea syndrome. Respir Med. 2005 May;99(5):529-34.

147. Serrano-Pariente J, Plaza V, Soriano JB, Mayos M, López-Viña A, Picado C. Vigil L; CPASMA Trial Group. Asthma outcomes improve with continuous positive airway pressure for obstructive sleep apnea. Allergy. 2017 May;72(5): 802-12. https://doi.org/10.1111/all.13070.

148. Kauppi P, Bachour P, Maasilta P, Bachour A. Long-term CPAP treatment improves asthma control in patients with asthma and obstructive sleep apnoea. Sleep Breath. 2016 Dec;20(4):1217-24. https://doi.org/10.1007/ s11325-016-1340-1.

149. Lafond C, Sériès F, Lemière $C$. Impact of CPAP on asthmatic patients with obstructive sleep apnoea. Eur Respir J. 2007;29:307-11. https://doi.org/10. 1183/09031936.00059706.

150. Ng SSS, Chan TO, To KW, Chan KKP, Ngai J, Yip WH, Lo RLP, Ko FWS, Hui DSC. Continuous positive airway pressure for obstructive sleep apnoea does not improve asthma control. Respirology. 2018;23:1055-62. https://doi.org/ 10.1111/resp.13363.

151. Davies SE, Bishopp A, Wharton S, Turner AM, Mansur AH. Does Continuous Positive Airway Pressure (CPAP) treatment of obstructive sleep apnoea (OSA) improve asthma-related clinical outcomes in patients with co-existing 
conditions? A systematic review. Respir Med. 2018;143:18-30. https://doi. org/10.1016/j.rmed.2018.08.004.

152. Teodorescu M, Broytman O, Curran-Everett D, Sorkness RL, Crisafi G, Bleecker ER, Erzurum S, Gaston BM, Wenzel SE, Jarjour NN. National Institutes of Health, National Heart, Lung and Blood Institute Severe Asthma Research Program (SARP) Investigators. Obstructive Sleep Apnea Risk, Asthma Burden, and Lower Airway Inflammation in Adults in the Severe Asthma Research Program (SARP) II. J Allergy Clin Immunol Pract. 2015;3: 566-575.e1. https://doi.org/10.1016/j.jaip.2015.04.002.

153. Almendros I, Martinez-Garcia MA, Obeso A, Gozal D. Obstructive sleep apnea and cancer: insights from intermittent hypoxia experimental models. Curr Sleep Medicine Rep. 2017;3:22-9. https://doi.org/10.1007/s40675-017-0064-5.

154. Yoon DW, So D, Min S, Kim J, Lee M, Khalmuratova R, Cho CH, Park JW, Shin HW. Accelerated tumor growth under intermittent hypoxia is associated with hypoxia-inducible factor-1-dependent adaptive responses to hypoxia. Oncotarget. 2017:8(37):61592-61603. doi: 10.18632/oncotarget.18644.

155. Nieto FJ, Peppard PE, Young T, Finn L, Hla KM, Farré R. Sleep-disordered breathing and cancer mortality: results from the Wisconsin Sleep Cohort Study. Am J Respir Crit Care Med. 2012;186:190-4. https://doi.org/10.1164/ rccm.201201-01300C.

156. Marshall NS, Wong KK, Cullen SR, Knuiman MW, Grunstein RR. Sleep apnea and 20-year follow-up for all-cause mortality, stroke, and cancer incidence and mortality in the Busselton Health Study cohort. J Clin Sleep Med. 2014; 10:355-62. https://doi.org/10.5664/jcsm.3600.

157. Martínez-García MA, Campos-Rodriguez F, Durán-Cantolla J, de la Peña M, Masdeu MJ, González M, Del Campo F, Serra PC, Valero-Sánchez I, Ferrer MJ, Marín JM, Barbé F, Martínez M, Farré R, Montserrat JM. Spanish Sleep Network. Obstructive sleep apnea is associated with cancer mortality in younger patients. Sleep Med. 2014;15:742-8. https://doi.org/10.1016/j.sleep.2014.01.020.

158. Li L, Lu J, Xue W, Wang L, Zhai Y, Fan Z, Wu G, Fan F, Li J, Zhang C, Zhang Y, Zhao J. Target of obstructive sleep apnea syndrome merge lung cancer: based on big data platform. Oncotarget. 2017;8: 21567-21578. doi:10.18632/ oncotarget.15372.

159. Gozal D, Ham SA, Mokhlesi B. Sleep Apnea and cancer: analysis of a nationwide population sample. sleep. 2016;39:1493-500. https://doi.org/10. 5665/sleep.6004

160. Vilaseca A, Nguyen DP, Vertosick EA, Corradi RB, Musquera M, Pérez M, Fossati N, Sjoberg DD, Farré R, Almendros I, Montserrat JM, Benfante NE, Hakimi AA, Skanderup AJ, Russo P, Alcaraz A, Touijer KA. Obstructive sleep apnea and Fuhrman grade in patients with clear cell renal cell carcinoma treated surgically. World J Urol. 2017;35(1):51-6. https://doi.org/10.1007/ s00345-016-1830-6.

161. Dal Molin M, Brant A, Blackford AL, Griffin JF, Shindo K, Barkley T, Rezaee N, Hruban RH, Wolfgang CL, Goggins M. Obstructive sleep apnea and pathological characteristics of resected pancreatic ductal adenocarcinoma. PLoS One. 2016;11:e0164195. https://doi.org/10.1371/journal.pone.0164195.

162. Campos-Rodriguez F, Martinez-Garcia MA, Martinez M, Duran-Cantolla J, Peña Mde L, Masdeu MJ, Gonzalez M. Campo Fd, Gallego I, Marin JM, Barbe F, Montserrat JM, Farre R; Spanish Sleep Network. Association between obstructive sleep apnea and cancer incidence in a large multicenter Spanish cohort. Am J Respir Crit Care Med. 2013;187:99-105. https://doi.org/ 10.1164/rccm.201209-16710C.

163. Chang WP, Liu ME, Chang WC, Yang AC, Ku YC, Pai JT, Lin YW, Tsai SJ. Sleep apnea and the subsequent risk of breast cancer in women: a nationwide population-based cohort study. Sleep Med. 2014;15:1016-20. https:/doi.org/ 10.1016/j.sleep.2014.05.026

164. Chen JC, Hwang JH. Sleep apnea increased incidence of primary central nervous system cancers: a nationwide cohort study. Sleep Med. 2014;15: 749-54. https://doi.org/10.1016/j.sleep.2013.11.782.

165. Sillah A, Watson NF, Schwartz SM, Gozal D, Phipps Al. Sleep apnea and subsequent cancer incidence. Cancer Causes Control. 2018;29:987-94. https://doi.org/10.1007/s10552-018-1073-5.

166. Christensen AS, Clark A, Salo P, Nymann P, Lange P, Prescott E, Rod NH. Symptoms of sleep disordered breathing and risk of cancer: a prospective cohort study. Sleep. 2013;36:1429-35. https://doi.org/10.5665/sleep.3030.

167. Kendzerska T, Leung RS, Hawker G, Tomlinson G, Gershon AS. Obstructive sleep apnea and the prevalence and incidence of cancer. CMAJ. 2014;186: 985-92. https://doi.org/10.1503/cmaj.140238.

168. Palamaner Subash Shantha G, Kumar AA, Cheskin LJ, Pancholy SB. Association between sleep-disordered breathing, obstructive sleep apnea, and cancer incidence: a systematic review and meta-analysis. Sleep Med. 2015;16:1289-94. https://doi.org/10.1016/.sleep.2015.04.014.

169. Zhang XB, Peng LH, Lyu Z, Jiang XT, Du YP. Obstructive sleep apnoea and the incidence and mortality of cancer: a meta-analysis. Eur J Cancer Care (Engl). 2017;26. https://doi.org/10.1111/ecc.12427.

170. Martínez-García MÁ, Martorell-Calatayud A, Nagore E, Valero I, Selma MJ, Chiner E, Landete P, Montserrat JM, Carrera C, Pérez-Gil A, CamposRodríguez F, Farré R. Association between sleep disordered breathing and aggressiveness markers of malignant cutaneous melanoma. Eur Respir J. 2014;43:1661-8. https://doi.org/10.1183/09031936.00115413.

171. Martínez-García MÁ, Riveiro-Falkenbach E, Rodríguez-Peralto JL, Nagore E, Martorell-Calatayud A, Campos-Rodríguez F, Farré R, Hernández Blasco L, Bañuls Roca J, Chiner Vives E, Sánchez-de-la-Torre A, Abad Capa J, Montserrat JM, Almendros I, Pérez-Gil A, Cabriada Nuño V, Cano-Pumarega I, Corral Peñafiel J, Diaz Cambriles T, Mediano O, Dalmau Arias J, Gozal D. Spanish Sleep Network. A prospective multicenter cohort study of cutaneous melanoma: clinical staging and potential associations with HIF1a and VEGF expressions. Melanoma Res. 2017;27:558-64. https://doi.org/10. 1097/CMR.0000000000000393.

172. Santamaria-Martos F, Benítez I, Girón C, Barbé F, Martínez-García MA, Hernández L, Montserrat JM, Nagore E, Martorell A, Campos-Rodriguez F, Corral J, Cabriada V, Abad J, Mediano O, Troncoso MF, Cano-Pumarega I, Fortuna Gutierrez AM, Diaz-Cambriles T, Somoza-Gonzalez M, Almendros I, Farre R, Gozal D, Sánchez-de-la-Torre M; Spanish Sleep Network. Biomarkers of carcinogenesis and tumour growth in patients with cutaneous melanoma and obstructive sleep apnoea. Eur Respir J. 2018; 51(3). pii: 1701885. doi: https://doi.org/10.1183/13993003.01885-2017.

173. Almendros I, Martínez-García MÁ, Campos-Rodríguez F, Riveiro-Falkenbach E, Rodríguez-Peralto JL, Nagore E, Martorell-Calatayud A, Hernández Blasco L, Bañuls Roca J, Chiner Vives E, Sánchez-de-la-Torre A, Abad-Capa J, Montserrat JM, Pérez-Gil A, Cabriada-Nuño V, Cano-Pumarega I, CorralPeñafiel J, Diaz-Cambriles T, Mediano O, Dalmau-Arias J, Farré R, Gozal D. Spanish Sleep Network. Intermittent hypoxia is associated with high hypoxia inducible factor-1a but not high vascular endothelial growth factor cell expression in tumors of cutaneous melanoma patients. Front Neurol. 2018;9:272. https://doi.org/10.3389/fneur.2018.00272.

174. Randerath W, Bassetti CL, Bonsignore MR, Farre R, Ferini-Strambi L, Grote L, Hedner J, Kohler M, Martinez-Garcia M, Mihaicuta S, Montserrat J, Pepin JL, Pevernagie D, Pizza F, Polo O, Riha R, Ryan S, Verbraecken J, McNicholas WT. Challenges and perspectives in obstructive sleep apnoea: Report by an ad hoc working group of the Sleep Disordered Breathing Group of the European Respiratory Society and the European Sleep Research Society. Eur Respir J. 2018. https://doi.org/10.1183/13993003.02616-2017.

175. Pépin JL, Bailly S, Tamisier R. Incorporating polysomnography into obstructive sleep apnoea phenotyping: moving towards personalised medicine for OSA. Thorax. 2018;73:409-11. https://doi.org/10.1136/thoraxjnl2017-210943. 